\title{
Relationships Among Leaders' and Followers' Work Engagement and Followers' Subjective Career Success: A Multilevel Approach
}

\author{
Qishan Chen ${ }^{1,2 *}$, Shuting Yang ${ }^{3}$, Jiayu Deng ${ }^{1,2}$, Liuying $\mathrm{Lu}^{1,2}$ and Jingyi $\mathrm{He}^{1,2}$ \\ ${ }^{1}$ Key Laboratory of Brain, Cognition and Education Sciences, Ministry of Education, Guangzhou, China, ${ }^{2}$ Guangdong Key \\ Laboratory of Mental Health and Cognitive Science, Center for Studies of Psychological Application, School of Psychology, \\ South China Normal University, Guangzhou, China, ${ }^{3}$ Beijing Key Laboratory of Applied Experimental Psychology, Faculty of \\ Psychology, National Demonstration Center for Experimental Psychology Education (Beijing Normal University), Beijing \\ Normal University, Beijing, China
}

\section{OPEN ACCESS}

Edited by:

Tahir Farid,

Zhejiang University, China

Reviewed by:

Azlyn Ahmad Zawawi, MARA University of

Technology, Malaysia

Nur Zafifa Kamarunzaman,

MARA University of

Technology, Malaysia

*Correspondence:

Qishan Chen

kaisanchan@163.com

Specialty section:

This article was submitted to

Organizational Psychology,

a section of the journal

Frontiers in Psychology

Received: 27 November 2020 Accepted: 28 January 2021

Published: 11 March 2021

Citation:

Chen Q, Yang S, Deng J, Lu L and $\mathrm{He} \mathrm{J} \mathrm{(2021)} \mathrm{Relationships} \mathrm{Among}$ Leaders' and Followers' Work Engagement and Followers'

Subjective Career Success: A

Multilevel Approach.

Front. Psychol. 12:634350.

doi: 10.3389/fpsyg.2021.634350
Using a sample of 52 work teams (52 work team leaders and their 348 followers) in China, we investigated the influence mechanism of leaders' work engagement on their followers' work engagement and subjective career success. A multilevel structural equation model (MSEM) was applied to analyze the survey data. The results of this study indicated that leaders' work engagement positively influenced their followers' subjective career success, and this relationship was mediated by the followers' work engagement. Implications of these findings, limitations, and directions for future research are discussed in the final section of the paper.

\section{Keywords: work engagement, subjective career success, work team, leader, follower, multilevel model}

\section{INTRODUCTION}

Career success is the goal eagerly pursued by every employee. As it plays an important role in individual lives, organizations, and even society, the past decades have shown a dramatic increase in research interest in career success in both theory and practice (Arthur et al., 2005; Heslin, 2005; Ng et al., 2005; Ng and Feldman, 2014; Hirschi et al., 2018; Heslin et al., 2019; Smale, 2019; Spurk et al., 2019).

In recent years, the research on career success has received growing attention in the fields of psychology and organizational science, especially in studies that have focused on its impact factors (Ramaswami et al., 2010, 2016; De Vos et al., 2011; Stumpf and Tymon Jr, 2012; Spurk and Abele, 2014; Zacher, 2014; Deng et al., 2015; Hirschi and Jaensch, 2015; Akkermans and Tims, 2017; Cenciotti et al., 2017; Hirschi et al., 2018; Suutari et al., 2018). A meta-analysis revealed four categories of predictors of objective and subjective career success: human capital, organizational sponsorship, sociodemographic status, and stable individual differences (Ng et al., 2005; Spurk et al., 2019). With regard to subjective career success, Ng and Feldman (2014) found that it was significantly related to dispositional traits (e.g., emotional stability), social networks (e.g., supervisor support), organizational and job support (e.g., job insecurity), and motivation (e.g., work engagement).

Work engagement is currently one of the most studied topics in organizational science, and it is closely tied to employees' career success. Considerable evidence has proven the impact of work engagement on career success. Ng et al.'s (2005) meta-analysis and Breevaart et al.'s (2015) work indicated that work engagement can predict objective career success and that it was positively correlated with subjective career success. Although many studies have been conducted on the 
relationship between work engagement and career success, the existing studies have tended to investigate this relationship from an individual perspective (individual level) rather than from a work team perspective (multilevel).

The main purpose of the present research is to examine the influence of team leaders' work engagement on their followers' subjective career success and the multilevel mediating effect of followers' work engagement from a multilevel perspective.

\section{Subjective Career Success}

Career success is defined as an accumulated positive psychological accomplishment, and work outcomes resulting from individual work experiences encompass both objective and subjective criteria (Arthur et al., 2005; Pan and Zhou, 2015; Shockley et al., 2016). Researchers distinguish subjective career success from objective career success that can be directly observed, measured, and verified by an impartial third party, while subjective career success is defined as the focal career actor's evaluation and experience of achieving personally meaningful career outcomes including that actor's internal apprehension, perceptual evaluation, and sense of his or her own career success (Judge et al., 2010; Hogan et al., 2013; Shockley et al., 2016).

A research found that an increasing number of employees define their career success in terms of subjective indicators, such as job satisfaction or career satisfaction, rather than in terms of objective indicators, such as salary and promotion (Ng and Feldman, 2014). Although objective and subjective career successes are considered to be positively related, the two constructs are empirically distinct. Career success cannot be predicted solely through salary or promotion. In contrast, some people may consider their career success in terms of job satisfaction.

The antecedents of subjective career success have been extensively researched. The research has found that marital status, educational level, and degree type can predict objective success. In contrast, motivational and organizational variables have been found to explain significant amounts of variance in subjective success (Mohd Rasdi et al., 2011). A metaanalysis of 216 independent samples, representing a total of 12,567 employees, showed that career hurdles, job insecurity, low emotional stability, low supervisor support, and low work engagement were all significantly related to lower subjective career success (Ng and Feldman, 2014).

Employees' subjective career success is especially influenced by their perceptions and reactions to their current jobs and organizations (Ng et al., 2005; Ng and Feldman, 2014; Baethge et al., 2017; Moon and Choi, 2017; Peng et al., 2019). Therefore, particular attention must be paid to the issue of work engagement in relation to job perception. In addition, the variables at the team level have a significant impact on employees' subjective career success. Hence, we must also pay more attention to how leaders' character influences followers' subjective career success.

\section{From Leaders' Work Engagement to Followers' Work Engagement}

Work engagement is a fulfilling, positive work-related state of mind that is characterized by vigor, dedication, and absorption
(Bakker et al., 2011; Vigoda-Gadot et al., 2013). Vigor refers to high levels of energy and mental resilience in working. Dedication refers to being strongly involved and experiencing a sense of significance, enthusiasm, and challenge in one's work. Absorption is characterized by being fully concentrated and happily engrossed in work such that time passes quickly (Bakker and Leiter, 2010; Schaufeli and Bakker, 2010; Bakker, 2011).

A work team consists of team members who have the same commitment and responsibility to achieve a particular goal or to accomplish a task. Because a work team operates in an organizational context, information communication and interpersonal interactions occur between team leaders and followers as well as among followers (Hart and Mcleod, 2003; Kozlowski and Bell, 2003; Loi et al., 2017).

The team leader not only instructs and supervises the followers but also offers them information and resources in their daily work. Followers accept orders from the leader and accomplish their assigned tasks. During this process, the leader's psychological and work state may influence the followers' work attitude and behavior in formal and informal ways.

Work engagement is conceptualized as a state with important characteristics such as openness to development and the existence of contagion effects. In other words, the work engagement in the leader-follower relationship and the work engagement in the follower-follower relationship could easily impact one another (Bakker and Xanthopoulou, 2009; Schaufeli et al., 2009; Zhu et al., 2009; Zettler and Hilbig, 2010; Gutermann et al., 2017; Lu et al., 2018).

Such influence varies with leaders. Leaders who are more engaged in work tend to be hopeful, motivated to succeed, and likely to establish challenging goals. They are willing to explore ways to solve problems. In other words, they have positive expectations of the work environment, resulting in a positive attitude and strong job performance. Leaders' with such characteristics and behavior will easily affect their followers and cause them to experience more positive emotions, which may accordingly improve their work engagement (Johnson, 2009; Tims et al., 2011; Gutermann et al., 2017). Conversely, it is difficult to imagine how team members might be inspired and encouraged by an unengaged leader.

Moreover, leaders are always regarded as examples for their followers to imitate. In this way, leaders become an influential source of information for their followers regarding appropriate attitudes and behaviors. If leaders display high levels of work engagement, their team will be willing to observe and perceive the positive work results of their leaders' work engagement. It would be beneficial for team members to develop positive and optimistic job expectations as well as a stronger motivation for success, which could increase their work engagement (Schaufeli et al., 2009; Ambrose et al., 2013; Lehmann-Willenbrock et al., 2015).

Therefore, in this research, we propose the following hypothesis:

Hypothesis 1: Leaders' work engagement positively relates to their followers' work engagement. 


\section{Followers' Work Engagement and Subjective Career Success}

In recent years, a large number of studies in the fields of psychology and management have shown that work engagement contributes to desired job outcomes for both individuals and organizations (Shuck and Herd, 2012; Carasco-Saul et al., 2015). As a positive work-relevant experience and a condition of mind, work engagement is important for individuals in the process of improving themselves and achieving success. According to the job demands-resources (JD-R) model (Bakker and Demerouti, 2008), employees who have job resources and personal resources are confident in their abilities and are optimistic about their future. This allows them to be more engaged in their jobs and to avoid job burnout. Thus, they will remain motivated and able to better cope with work challenges and achieve career success (Xanthopoulou et al., 2007; Akkermans et al., 2013; Chen et al., 2018).

Empirical studies have supported the general belief that work engagement contributes to subjective career success (job satisfaction). For example, Ng and Feldman (2014) and Elams-Atay (2017) found that work engagement was positively correlated to subjective career success. In addition, work engagement was predictive of job performance and satisfaction (Breevaart et al., 2015; Eldor and Harpaz, 2016; Guo et al., 2017; Ngo and Hui, 2017).

Bakker et al. (2008) noted that engaged workers perform better than unengaged workers because they often experience positive emotions, including happiness, joy, and enthusiasm; maintain better psychological and physical health; conserve their own job and personal resources (e.g., support from others); and communicate their engagement to others.

Thus, we expect work engagement comprising vigor, dedication, and absorption to improve follower subjective career success by enhancing an individual's overall motivation and perseverance. We propose the following hypothesis:

Hypothesis 2: Followers' work engagement positively relates to their subjective career success.

An engaged leader plays an important role in the team. Engaged leaders have been found to be more loyal to their organizations and often maintain better psychological and physical health (Bakker et al., 2008; Halbesleben and Wheeler, 2008; Schaufeli et al., 2009). In addition, leaders who are more engaged can communicate their engagement to their followers (Bakker and Xanthopoulou, 2009; Gutermann et al., 2017). Although leaders' work engagement has an important impact, followers' work engagement is also necessary for followers' career success. It is unlikely for a team member to achieve career success without his or her own engagement.

To extend the previous research on work engagement and follow the logic of hypotheses 1 and 2, we regard leaders' work engagement as a more distal predictor of followers' subjective career success. We believe that leaders' work engagement is likely to play a role in followers' subjective career success by enhancing their work engagement. Supporting this argument, VincentHöper et al. (2012) reported that employees' work engagement was found to partially mediate the relationship between transformational leadership characteristics and subjective career success. Many studies have also found that employees' work engagement mediates the link between leaders' relational behaviors and employees' job attitude and performance (Shuck and Herd, 2012; Carasco-Saul et al., 2015).

Based on these findings, we expect followers' work engagement to serve as a mediator of the relationship between leaders' work engagement and followers' subjective career success. We therefore propose the following hypothesis:

Hypothesis 3: Followers' work engagement mediates the positive relationship between leaders' work engagement and their followers' subjective career success.

To summarize, the hypothesized model is as follows (Figure 1).

\section{METHODS}

\section{Participants}

The participants in this research were work teams from 14 public enterprises in Guangdong Province, China. They were similar in terms of their organizational forms, work tasks, work patterns, and performance assessment criteria. A total of 480 questionnaires were distributed in this investigation, and 400 valid questionnaires from both leaders and team members were collected, for an $83.3 \%$ participation rate. We collected valid data from a total of 52 work teams, the number of which ranged from 3 to 15 , with 7 team members on average. In every work team, each employee has worked with his or her direct supervisor for at least 1 year, with an average of 6.9 years. Of all the participants, $16.4 \%$ were males, and $83.6 \%$ were females. The age of the participants ranged from 21 to 59 years old, with an average age of 34. The education background of the participants varied from middle school education to master's and above, with $0.3 \%$ having completed middle school education and below; $4.9 \%$ having completed high school, vocational high school, technical school, or technical secondary school; $43.3 \%$ having completed junior college; $51.2 \%$ having completed undergraduate education; and $0.3 \%$ having completed master's education and above. The length of work of all the participants averaged 12.23 years.

The present research was approved by the research ethics committee of the respective university (referral number: SCNUPSY-335). All participants provided their written consent before completing the questionnaires. The data were collected and analyzed anonymously.

\section{Measures \\ Work Engagement}

We adopted the Utrecht Work Engagement Scale (UWES) developed by Schaufeli et al. (2002) to measure the participants' work engagement. This 17-item scale contained three dimensions-vigor, dedication, and absorption-with 6, 5, and 6 items for each dimension, respectively. In the present research, we used a 5-point Likert measure $(1=$ strongly disagree, $2=$ disagree, $3=$ not sure, $4=$ agree, and $5=$ strongly agree). The Cronbach's alpha coefficients of leaders' work engagement in vigor, dedication, and absorption were $0.86,0.89$, and 0.85 , respectively; those of the followers' work 


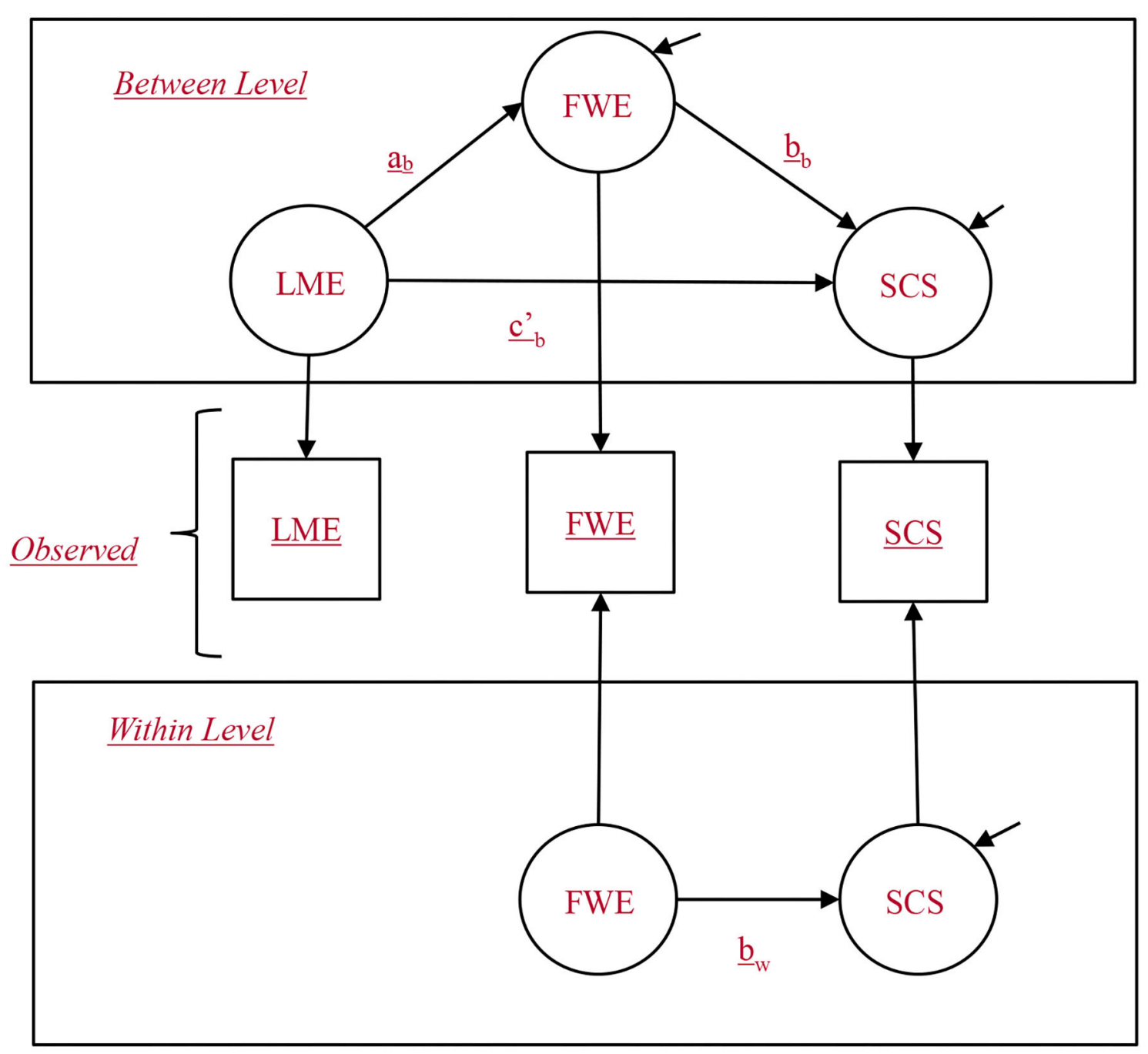

FIGURE 1 | Multilevel structural equation model for the 2-1-1 hypothesized model. SCS, subjective career success; LWE, leaders' work engagement; FWE, followers' work engagement. b subscript represents between level and w subscript represents within level.

engagement were $0.88,0.87$, and 0.85 , respectively. The $\operatorname{ICC}(1)$ of followers' work engagement was 0.293 . Because $\operatorname{ICC}(1)>0.059$, between-group differences existed and could not be neglected (Cohen, 1988).

\section{Subjective Career Success}

We adopted a 5-item scale, the Career Satisfaction Scale, to measure followers' subjective career success. This onedimensional scale was developed by Greenhaus et al. (1990) and has been widely used in research. In the present research, we used a 5 -point Likert measure ( $1=$ strongly disagree, $2=$ disagree, 3 $=$ not sure, $4=$ agree, and $5=$ strongly agree). The Cronbach's alpha coefficient of the scale was 0.67 . The ICC(1) of subjective career success was 0.203 .

\section{Measurements and Data Analysis}

We sent self-reported questionnaires to both team leaders and followers. The questionnaire for the leaders included a work engagement measurement, while the questionnaire for the followers contained both a subjective career success scale and a work engagement scale. To reduce the participants' concerns and to protect their privacy, all the questionnaires and test compensation were enclosed and sealed in envelopes in advance. On the cover of the questionnaires, the following statement was included: "To protect your privacy, please return the completed questionnaire in the envelope and seal it well." The participants were assigned a random number for identification and matching.

Regarding the questionnaires for the followers, we adopted Harman's one-factor test to examine common method variance (Malhotra et al., 2006). The goodness-of-fit index of the onefactor model and four-factor model are as follows, respectively: $\chi^{2}=888.99, \mathrm{df}=152, \mathrm{RMSEA}=0.118, \mathrm{TLI}=0.78, \mathrm{CFI}=0.80$, and SRMR $=0.068$ (one-factor) $; \chi^{2}=517.82, \mathrm{df}=146$, RMSEA $=0.086, \mathrm{TLI}=0.88, \mathrm{CFI}=0.90$, and $\mathrm{SRMR}=0.056$ (four-factor). The result that the four-factor model fit better than the one-factor 
model revealed that common method variance was possible in the present research; however, its influence could be small.

SPSS 21.0 was used in this research to perform descriptive statistics, correlation analyses, exploratory factor analysis, and reliability analysis. We used Mplus 7.4 (Muthén and Muthén, 1998-2015) to conduct confirmatory factor analysis and multilevel structural equation modeling (MSEM). Missing data accounted for $<5 \%$, and we adopted the EM algorithm to account for it.

\section{RESULTS}

\section{Descriptive Statistics}

The descriptive statistics are shown in Table 1. Leaders' work engagement was positively correlated with followers' work engagement and subjective career success. This was the basis for the next mediation analysis. Followers' educational background was significantly correlated with both followers' work engagement and followers' subjective career success. Thus, followers' educational background was controlled for in our subsequent data analyses.

\section{The Influence of Leaders' Work Engagement on Their Followers' Subjective Career Success: Multilevel Mediation Effect of Followers' Work Engagement}

Team leaders' work engagement was a group-level variable, whereas followers' work engagement and their subjective career success were individual-level variables. We followed Preacher et al. $(2010,2011)$ recommendations to test the 2-1-1 mediation model.

As shown in Table 2, team leaders' work engagement had a positive effect on followers' subjective career success $(\beta=0.192$, $p<0.05)$. Followers' work engagement had a positive effect on followers' subjective career success $(\beta=0.994, p<0.001)$. The results showed a significant indirect effect of team leaders' work engagement on followers' subjective career success via followers' work engagement [ $\mathrm{ab}=0.191, p<0.05,95 \% \mathrm{CI}(0.019$, $0.391)]$. Here, we used the open-source software R to compute the $95 \%$ confidence interval by resampling the parameter estimates generated by Mplus (samples = 20,000).

\section{DISCUSSION}

\section{Leaders' Work Engagement and Followers' Work Engagement and Subjective Career Success}

Considerable evidence about the influencing factors of subjective career success in the fields of psychology and organization science has shown that all the individual-level, group-level, and organizational-level variables have important impacts on individual subjective career success (reviews see $\mathrm{Ng}$ et al., 2005; Ng and Feldman, 2014; Spurk et al., 2019). Using a multilevel approach, the present study investigated the relationships among leaders' work engagement, followers' work engagement, and subjective career success. The results showed that leaders' work engagement positively affects their followers' work engagement, which affects followers' subjective career success.

The working environment is an important source of information for working group members. Various types of information, such as leaders' characteristics and working climate, will affect individuals' work attitudes and behaviors formally and informally.

Employees will influence one another in the workplace. The process by which the psychological well-being experienced by one person affects the level of well-being of another person is referred to as crossover (Bakker et al., 2009; Wirtz et al., 2017). Crossover is a dyadic, interindividual transmission of well-being between closely related individuals that occurs within a particular domain. As a positive state of mind, one's work engagement can crossover within the organization and affect other employees' work engagement, especially when the two are closely linked with the same tasks or emotions (Bakker et al., 2009). Bakker et al. (2006) examined the crossover of work engagement. The results of multilevel analyses confirmed that team-level work engagement is related to team members' work engagement after controlling for members' job demands and resources. The results of this study suggested that leaders' work engagement influenced followers' work engagement. Leaders who were vigorous, dedicated, and absorbed tended to have a positive attitude toward their work environment. They tended to be highly motivated and showed persistence in reaching their goals. As the followers observe the positive impact of their leaders' work engagement, they were more likely to emulate the behaviors associated with work engagement.

We also proposed that this effect may occur through the process of emotional contagion, thereby forming a homogenous emotional state and social cognitive state among work team members (Barsade and Gibson, 2012; Collins et al., 2013). Leaders play an important role in the formation of group emotions. Teams with a leader who shows more positive emotions are usually equipped with more enthusiasm and striving spirit. Leaders' emotions can not only influence followers in the short term but also determine the whole atmosphere of the team in the long term such that followers will be immersed in a positive or negative state of emotion for a long time. Future research can examine the role of emotional contagion in this process and test whether emotional contagion mediates the influence effect of leaders' work engagement on their followers' work engagement.

Subjective career success is considered to be an important outcome variable of work engagement and has been discussed by many studies. Some studies have indicated that work engagement is related to subjective career success, and many of them have revealed that work engagement acts as a mediator between many antecedent variables and subjective career success (Demerouti et al., 2001; Bakker et al., 2008; Giallonardo et al., 2010; Karatepe, 2012; Laschinger, 2012; Karanika-Murray et al., 2015; Jawahar and Liu, 2017). For example, Jawahar and Liu (2017) found that a proactive personality is an antecedent of job and career satisfaction, and work engagement mediates these relationships. Karanika-Murray et al. (2015) tested two models in 
TABLE 1 | Descriptive statistics.

\begin{tabular}{|c|c|c|c|c|c|c|c|c|c|c|c|}
\hline Variables & $M$ & SD & 1 & 2 & 3 & 4 & 5 & 6 & 7 & 8 & 9 \\
\hline 1. Leaders' work engagement & 4.03 & 0.63 & - & & & & & & & & \\
\hline 2. $\operatorname{Sex}^{\mathrm{a}}$ & 0.16 & - & - & - & & & & & & & \\
\hline 3. Age & 34.84 & 8.58 & - & $0.15^{\star \star}$ & - & & & & & & \\
\hline 4. Educational background & 3.46 & 0.61 & - & 0.04 & $-0.38^{\star \star}$ & - & & & & & \\
\hline 5. Working years & 12.23 & 9.37 & - & $0.12^{\star}$ & $0.95^{\star \star}$ & $-0.36^{\star \star}$ & - & & & & \\
\hline 6. Years working in this position & 6.88 & 7.24 & - & $0.12^{*}$ & $0.73^{\star *}$ & $-0.32^{\star \star}$ & $0.72^{\star \star}$ & - & & & \\
\hline 7. Income & 2.24 & 0.74 & - & $0.25^{\star \star}$ & $0.52^{\star \star}$ & 0.07 & $0.52^{\star \star}$ & $0.40^{\star \star}$ & - & & \\
\hline 8. Followers' work engagement & 3.74 & 0.73 & $0.19^{\star \star}$ & -0.04 & 0.04 & $-0.18^{\star \star}$ & 0.03 & -0.02 & -0.08 & - & \\
\hline 9. Subjective career success & 3.15 & 0.90 & $0.15^{\star \star}$ & -0.04 & 0.02 & $-0.20^{\star \star}$ & 0.02 & 0.02 & -0.01 & $0.54^{\star \star}$ & - \\
\hline
\end{tabular}

${ }^{* *} p<0.01,{ }^{*} p<0.05 ;{ }^{a} 0=$ female, $1=$ male, mean value of sex represented data of male followers. The leaders' work engagement reflected group-level (work team) data.

TABLE 2 | Multilevel mediation effect of followers' work engagement.

\begin{tabular}{|c|c|c|c|c|}
\hline & \multicolumn{2}{|c|}{ M (Fworen) } & \multicolumn{2}{|c|}{$Y$ (SCS) } \\
\hline & Estimate & SE & Estimate & SE \\
\hline \multicolumn{5}{|l|}{ Between level } \\
\hline Intercept & $2.957^{\star \star \star}$ & 0.371 & -0.578 & 0.510 \\
\hline$X_{\mathrm{b}}$ (Lworen) & $0.192^{\star}$ & 0.088 & 0.002 & 0.081 \\
\hline$M_{\mathrm{b}}$ (Fworen) & - & - & $0.994^{\star * \star}$ & 0.177 \\
\hline Residual variances of $M_{b}$ & $0.133^{\star \star}$ & 0.039 & - & - \\
\hline Residual Variances of $Y_{\mathrm{b}}$ & - & - & 0.015 & 0.027 \\
\hline Indirect effect & $0.191^{\star}$ & & & \\
\hline \multicolumn{5}{|l|}{ Within level } \\
\hline$M_{w}$ (Fworen) & - & - & $0.531^{\star * \star}$ & 0.071 \\
\hline Variances of $M_{\mathrm{w}}$ & - & - & $0.525^{\star \star \star}$ & 0.049 \\
\hline
\end{tabular}

${ }^{*} p<0.05,{ }^{* \star} p<0.01,{ }^{* \star *} p<0.001$; SCS, subjective career success; Lworen, leaders' work engagement; Fworen, followers' work engagement; $b$ subscript represents between level; w subscript represents within level.

which work engagement and its constituent dimensions (vigor, dedication, and absorption) mediated the relationship between organizational identification and job satisfaction. Karatepe (2012) revealed that work engagement fully mediated the effects of co-workers and supervisor support on career satisfaction.

As the above findings suggested, recent works on the mediating effect of engagement on subjective career success have mainly focused on individual and organizational variables. However, the present research focused on group-level variables and presented leaders' work engagement as a more distal predictor of followers' subjective career success. The results showed that leaders' work engagement influenced their followers' subjective career success by enhancing their work engagement.

\section{Implications}

First, the results of the present research have theoretical implications for the research on organizational behavior and career success.

Although the influencing factors of subjective career success have been well-documented in the organizational behavior literature (Ng et al., 2005; Ng and Feldman, 2014; Spurk et al.,
2019), the effect of work engagement on subjective career success has been highlighted in the newly emerging literature (Bakker et al., 2008; Karanika-Murray et al., 2015; Jawahar and Liu, 2017). However, less attention has been given to how the interactive relationship between leaders' and their followers' work engagement influences followers' subjective career success. The present research revealed that leaders' work engagement, as a level 2 variable, could influence followers' subjective career success, a level 1 variable, by the mediation effect of followers' work engagement. In other words, followers' work engagement functioned as a cross-level complete mediator in the relationship between leaders' work engagement and followers' work engagement. These findings extend the perspective of the earlier work from the employee level to the group level. This research deepened and expanded our understanding of the mechanism of leaders' work engagement on their followers' subjective career success.

Moreover, our results have several practical implications for organizational management and team construction.

Career success serves as an accelerator and catalyst for individual development. At the same time, it is crucial for a work team or an organization to function efficiently and progress in the long term. In this way, we should pay attention to the cultivation and development of career success in the management process. In addition, considering the positive influence of leaders' and followers' work engagement on their subjective career success, we should focus on increasing work engagement.

Leaders' work engagement can positively predict followers' subjective career success with this relationship mediated by followers' work engagement. Therefore, leaders' work engagement can be promoted and followers' work engagement can be facilitated through various approaches.

\section{Research Limitations and Suggestions for Future Research}

First, it is important to note that the present research was conducted with participants (leaders and followers) in the Chinese cultural context. In consideration of numerous differences between oriental and occidental cultures, the results of the present research should be cautiously promoted in a crosscultural context. Moreover, due to major differences in terms of 
production mode, organizational culture, and employee welfare in different organizations, we should be cautious in generalizing the results of the present research to other organizations. In addition, we adopted self-reported questionnaires as the research method. Although it was tested by Harman's one-factor model, common method variance fundamentally could not be avoided in our results. Finally, although the data for this research came from two independent questionnaires measuring team leaders and followers and controlling for possible influences of additional variables such as education background, we cannot deny its cross-sectional nature. Due to the cross-sectional nature of the study, we cannot draw any causal inferences.

Based on the limitations and problems of the current research, we offer several suggestions for future research in the following respects.

First, more research must be conducted in a cross-cultural context seeking to explore the interaction between leaders' and followers' work engagement in different cultures and to examine the applicability of the mediation effect in various cultures. Second, to improve the external validity, we should expand our sample size with samples from different organizations in different industries. Third, future work could combine self-reported evaluation with peer assessment to measure variables, reduce the impact of common method variance, and explore the relationship between variables in a more comprehensive and objective way. Fourth, future research can conduct longitudinal studies to provide more convincing evidence in the causal inference of the results. Finally, future work should compare various possible hypotheses to examine whether they could explain or to what extent they could elucidate the interaction.

\section{REFERENCES}

Akkermans, J., Schaufeli, W. B., Brenninkmeijer, V., and Blonk, R. W. B. (2013). The role of career competencies in the Job Demands-Resources model. J. Vocat. Behav. 83, 356-366. doi: 10.1016/j.jvb.2013.06.011

Akkermans, J., and Tims, M. (2017). Crafting your career: how career competencies relate to career success via job crafting. Appl. Psychol. 66, 168-195. doi: 10.1111/apps.12082

Ambrose, M. L., Schminke, M., and Mayer, D. M. (2013). Trickle-down effects of supervisor perceptions of interactional justice: a moderated mediation approach. J. Appl. Psychol. 98, 678-689. doi: 10.1037/a0032080

Arthur, M. B., Khapova, S. N., and Wilderom, C. P. (2005). Career success in a boundaryless career world. J. Organ. Behav. 26, 177-202. doi: 10.1002/job.290

Baethge, A., Rigotti, T., and Vincent-Hoeper, S. (2017). How followers differing in career motivation gain career profits from transformational leaders: a longitudinal moderated mediation model. Front. Psychol. 8:1527. doi: 10.3389/fpsyg.2017.01527

Bakker, A. B. (2011). An evidence-based model of work engagement. Curr. Dir. Psychol. Sci. 20, 265-269. doi: 10.1177/0963721411414534

Bakker, A. B., Albrecht, S. L., and Leiter, M. P. (2011). Key questions regarding work engagement. Europ. J. Work Organ. Psychol. 20, 4-28. doi: 10.1080/1359432X.2010.485352

Bakker, A. B., and Demerouti, E. (2008). Towards a model of work engagement. Career Dev. Int. 13, 209-223. doi: 10.1108/136204308108 70476

Bakker, A. B., Emmerik, H. V., and Euwema, M. C. (2006). Crossover of burnout and engagement in work teams. Work Occup. 33, 464-489. doi: $10.1177 / 0730888406291310$

\section{CONCLUSION}

The results of a multilevel model demonstrated that leaders' work engagement was positively related to followers' subjective career success, with this relationship being mediated by followers' work engagement.

\section{DATA AVAILABILITY STATEMENT}

The raw data supporting the conclusions of this article will be made available by the authors, without undue reservation.

\section{ETHICS STATEMENT}

The studies involving human participants were reviewed and approved by Research Ethics Committee of South China Normal University. The patients/participants provided their written informed consent to participate in this study.

\section{AUTHOR CONTRIBUTIONS}

All authors listed have made substantial, direct, and intellectual contribution to the work and approved it for publication.

\section{FUNDING}

This research was funded by grants from the National Natural Science Foundation of China (31771245), 13th Five-Year Plan Research Project of Philosophy and Social Science in Guangdong, China (GD17XXL02), and Innovation Project of Educational Science in Guangdong, China (2016GXJK032).

Bakker, A. B., and Leiter, M. P. (2010). Work Engagement: A Handbook of Essential Theory and Research. New York, NY: Psychology Press. doi: 10.4324/9780203853047

Bakker, A. B., Schaufeli, W. B., Leiter, M. P., and Taris, T. W. (2008). Work engagement: an emerging concept in occupational health psychology. Work Stress 22, 187-200. doi: 10.1080/02678370802393649

Bakker, A. B., Westman, M., and Hetty van Emmerik, I. J. (2009). Advancements in crossover theory. J. Manage. Psychol. 24, 206-219. doi: 10.1108/02683940910939304

Bakker, A. B., and Xanthopoulou, D. (2009). The crossover of daily work engagement: test of an actor-partner interdependence model. J. Appl. Psychol. 94, 1562-1571. doi: 10.1037/a0017525

Barsade, S. G., and Gibson, D. E. (2012). Group affect: its influence on individual and group outcomes. Curr. Dir. Psychol. Sci. 21, 119-123. doi: 10.1177/0963721412438352

Breevaart, K., Bakker, A. B., Demerouti, E., and van den Heuvel, M. (2015). Leadermember exchange, work engagement, and job performance. J. Manage. Psychol. 30, 754-770. doi: 10.1108/JMP-03-2013-0088

Carasco-Saul, M., Kim, W., and Kim, T. (2015). Leadership and employee engagement: proposing research agendas through a review of literature. Human Resour. Dev. Rev. 14, 38-63. doi: 10.1177/15344843145 60406

Cenciotti, R., Alessandri, G., and Borgogni, L. (2017). Psychological capital and career success over time: the mediating role of job crafting. J. Leaders. Organiz. Studies 24, 372-384. doi: 10.1177/1548051816680558

Chen, S. L., Shih, C. T., and Chi, N. W. (2018). A multilevel job demands-resources model of work engagement: antecedents, consequences, and boundary conditions. Hum. Perform. 31, 282-304. doi: 10.1080/08959285.2018.1531867 
Cohen, J. (1988). Statistical Power Analysis for the Behavioral Sciences. 2nd ed. Hillsdale, NJ: Eribaum.

Collins, A. L., Lawrence, S. A., Troth, A. C., and Jordan, P. J. (2013). Group affective tone: a review and future research directions. J. Organ. Behav. 34, S43-S62. doi: $10.1002 /$ job. 1887

De Vos, A., De Hauw, S., and Van der Heijden, B. I. (2011). Competency development and career success: the mediating role of employability. J. Vocat. Behav. 79, 438-447. doi: 10.1016/j.jvb.2011.05.010

Demerouti, E., Bakker, A. B., Nachreiner, F., and Schaufeli, W. B. (2001). The job demands-resources model of burnout. J. Appl. Psychol. 86, 499-512. doi: 10.1037/0021-9010.86.3.499

Deng, J., Chen, Q., Yang, S., and Xu, Y. (2015). "Effect of leaders' work engagement on followers' subjective career success: a multi-level model," in Proceedings of Cross-Cultural Occupational Health Psychology Forum, eds T. Xie, L. Hale, and J. Zhang (Wuhan: The American Scholars Press), 40-48.

Elams-Atay, S. (2017). Work values fit and subjective career success: The moderating role of work engagement. Int. Rev. Manage. Marketing 7, 113-120.

Eldor, L., and Harpaz, I. (2016). A process model of employee engagement: the learning climate and its relationship with extra-role performance behaviors. J. Organ. Behav. 37, 213-235. doi: 10.1002/job.2037

Giallonardo, L. M., Wong, C. A., and Iwasiw, C. L. (2010). Authentic leadership of preceptors: predictor of new graduate nurses' work engagement and job satisfaction. J. Nurs. Manag. 18, 993-1003. doi: 10.1111/j.1365-2834.2010.01126.x

Greenhaus, J. H., Parasuraman, S., and Wormley, W. M. (1990). Effects of race on organizational experiences, job performance evaluations, and career outcomes. Acad. Manage. J. 33, 64-86. doi: 10.5465/256352

Guo, Y., Du, H., Xie, B., and Mo, L. (2017). Work engagement and job performance: the moderating role of perceived organizational support. Ann. Psychol. 33, 708-713. doi: 10.6018/analesps.33.3.238571

Gutermann, D., Lehmann-Willenbrock, N., Boer, D., Born, M., and Voelpel, S. C. (2017). How leaders affect followers' work engagement and performance: Integrating leader-member exchange and crossover theory. $\mathrm{Br}$. J. Manage. 28, 299-314. doi: 10.1111/1467-8551.12214

Halbesleben, J. R., and Wheeler, A. R. (2008). The relative roles of engagement and embeddedness in predicting job performance and intention to leave. Work Stress 22, 242-256. doi: 10.1080/02678370802383962

Hart, R. K., and Mcleod, P. L. (2003). Rethinking team building in geographically dispersed teams: one message at a time. Organ. Dyn. 31, 352-361. doi: 10.1016/S0090-2616(02)00131-6

Heslin, P. A. (2005). Conceptualizing and evaluating career success. J. Organ. Behav. 26, 113-136. doi: 10.1002/job.270

Heslin, P. A., Keating, L. A., and Minbashian, A. (2019). How situational cues and mindset dynamics shape personality effects on career outcomes. J. Manage. 45, 2101-2131. doi: 10.1177/0149206318755302

Hirschi, A., and Jaensch, V. K. (2015). Narcissism and career success: Occupational self-efficacy and career engagement as mediators. Pers. Individ. Dif. 77, 205-208. doi: 10.1016/j.paid.2015.01.002

Hirschi, A., Nagy, N., Baumeler, F., Johnston, C. S., and Spurk, D. (2018). Assessing key predictors of career success: development and validation of the career resources questionnaire. J. Career Assessment 26, 338-358. doi: $10.1177 / 1069072717695584$

Hogan, R., Chamorro-Premuzic, T., and Kaiser, R. B. (2013). Employability and career success: bridging the gap between theory and reality. Ind. Organ. Psychol. 6, 3-16. doi: 10.1111/iops.12001

Jawahar, I. M., and Liu, Y. (2017). Why are proactive people more satisfied with their job, career, and life? An examination of the role of work engagement. J. Career Dev. 44, 344-358. doi: 10.1177/0894845316656070

Johnson, S. K. (2009). Do you feel what I feel? Mood contagion and leadership outcomes. Leadersh. Quart. 20, 814-827. doi: 10.1016/j.leaqua.2009.06.012

Judge, T. A., Klinger, R. L., and Simon, L. S. (2010). Time is on my side: time, general mental ability, human capital, and extrinsic career success. J. Appl. Psychol. 95, 92-107. doi: 10.1037/a00 17594

Karanika-Murray, M., Duncan, N., Pontes, H. M., and Griffiths, M. D. (2015). Organizational identification, work engagement, and job satisfaction. $J$. Manage. Psychol. 30, 1019-1033. doi: 10.1108/JMP-11-2013-0359
Karatepe, O. M. (2012). Job resources, work engagement, and hotel employee outcomes: a time-lagged analysis. Econ. Res. 25, 644-665. doi: 10.1080/1331677X.2012.11517527

Kozlowski, S. W. J., and Bell, B. S. (2003). "Work groups and teams in organizations," in Handbook of Psychology (Vol. 12): Industrial and Organizational Psychology, eds W. C. Borman, D. R. Ilgen, and R. J. Klimoski (New York, NY: Wiley), 333-375.

Laschinger, H. K. S. (2012). Job and career satisfaction and turnover intentions of newly graduated nurses. J. Nurs. Manag. 20, 472-484. doi: $10.1111 / j .1365-2834.2011 .01293 . x$

Lehmann-Willenbrock, N., Meinecke, A. L., Rowold, J., and Kauffeld, S. (2015). How transformational leadership works during team interactions: a behavioral process analysis. Leadersh. Q. 26, 1017-1033. doi: 10.1016/j.leaqua.2015.07.003

Loi, R., Xu, A. J., Chow, C. W., and Kwok, J. M. (2017). Customer misbehavior and store managers' work-to-family enrichment: the moderated mediation effect of work meaningfulness and organizational affective commitment. Hum. Resour. Manage. 57, 1039-1048 doi: 10.1002/hrm.21883

$\mathrm{Lu}, \mathrm{X}$., Xie, B., and Guo, Y. (2018). The trickle-down of work engagement from leader to follower: the roles of optimism and self-efficacy. J. Bus. Res. 84, 186-195. doi: 10.1016/j.jbusres.2017.11.014

Malhotra, N. K., Kim, S. S., and Patil, A. (2006). Common method variance in IS research: a comparison of alternative approaches and a reanalysis of past research. Manage. Sci. 52, 1865-1883. doi: 10.1287/mnsc. 1060.0597

Mohd Rasdi, R., Ismail, M., and Garavan, T. N. (2011). Predicting Malaysian managers' objective and subjective career success. Int. J. Hum. Resour. Manage. 22, 3528-3549. doi: 10.1080/09585192.2011.560878

Moon, J. S., and Choi, S. B. (2017). The impact of career management on organizational commitment and the mediating role of subjective career success: the case of Korean R\&D employees. J. Career Dev. 44, 191-208. doi: $10.1177 / 0894845316643829$

Muthén, L. K., and Muthén, B. O. (1998-2015). Mplus User's guide (7th Ed.). Los Angeles, CA: Muthén \& Muthén.

Ng, T. W., Eby, L. T., Sorensen, K. L., and Feldman, D. C. (2005). Predictors of objective and subjective career success: a meta-analysis. Pers. Psychol. 58, 367-408. doi: 10.1111/j.1744-6570.2005.00515.x

Ng, T. W., and Feldman, D. C. (2014), Subjective career success: a meta-analytic review. J. Vocat. Behav. 85, 169-179. doi: 10.1016/j.jvb.2014.06.001

Ngo, H.-Y., and Hui, L. (2017). Individual orientations and career satisfaction. J. Career Dev. 45, 425-439. doi: 10.1177/0894845317706759

Pan, J., and Zhou, W. (2015). How do employees construe their career success: an improved measure of subjective career success. Int. J. Select. Assessment 23, 45-58. doi: 10.1111/ijsa.12094

Peng, Z., Gao, B., and Zhao, H. (2019). Coaching leadership and subordinates' career success: the mediating role of leader-member exchange. Soc. Behav. Personal. 47, 1-8. doi: 10.2224/sbp.8406

Preacher, K. J., Zhang, Z., and Zyphur, M. J. (2011). Alternative methods for assessing mediation in multilevel data: the advantages of multilevel SEM. Struct. Equat. Model. 18, 161-182. doi: 10.1080/10705511.2011.557329

Preacher, K. J., Zyphur, M. J., and Zhang, Z. (2010). A general multilevel SEM framework for assessing multilevel mediation. Psychol. Methods 15, 209-233. doi: $10.1037 / \mathrm{a} 0020141$

Ramaswami, A., Carter, N. M., and Dreher, G. F. (2016). Expatriation and career success: a human capital perspective. Hum. Relat. 69, 1959-1987. doi: $10.1177 / 0018726716630390$

Ramaswami, A., Dreher, G. F., Bretz, R., and Wiethoff, C. (2010). Gender, mentoring, and career success: the importance of organizational context. Pers. Psychol. 63, 385-405. doi: 10.1111/j.1744-6570.2010.01174.x

Schaufeli, W. B., and Bakker, A. B. (2010). "Defining and measuring work engagement: Bringing clarity to the concept," in Work Engagement: A Handbook of Essential Theory and Research, eds A. B. Bakker and M. P. Leiter (Psychology Press), 10-24.

Schaufeli, W. B., Bakker, A. B., and Van Rhenen, W. (2009). How changes in job demands and resources predict burnout, work engagement, and sickness absenteeism. J. Organ. Behav. 30, 893-917. doi: 10.1002/job.595

Schaufeli, W. B., Salanova, M., González-Romá, V., and Bakker, A. B. (2002). The measurement of engagement and burnout: a two sample confirmatory factor analytic approach. J. Happiness Stud. 3, 71-92. doi: 10.1023/a:1015630930326 
Shockley, K. M., Ureksoy, H., Rodopman, O. B., Poteat, L. F., and Dullaghan, T. R. (2016). Development of a new scale to measure subjective career success: a mixed-methods study. J. Organ. Behav. 37, 128-153. doi: 10.1002/job.2046

Shuck, B., and Herd, A. M. (2012). Employee engagement and leadership: exploring the convergence of two frameworks and implications for leadership development in HRD. Hum. Resour. Dev. Rev. 11, 156-181. doi: $10.1177 / 1534484312438211$

Smale, A., et al. (2019). Proactive career behaviors and subjective career success: the moderating role of national culture. J. Organ. Behav. 40, 105-122. doi: $10.1002 /$ job. 2316

Spurk, D., and Abele, A. E. (2014). Synchronous and time-lagged effects between occupational self-efficacy and objective and subjective career success: findings from a four-wave and 9-year longitudinal study. J. Vocat. Behav. 84, 119-132. doi: $10.1016 /$ j.jvb.2013.12.002

Spurk, D., Hirschi, A., and Dries, N. (2019). Antecedents and outcomes of objective versus subjective career success: competing perspectives and future directions. J. Manage. 45, 35-69. doi: 10.1177/0149206318786563

Stumpf, S. A., and Tymon Jr, W. G. (2012). The effects of objective career success on subsequent subjective career success. J. Vocat. Behav. 81, 345-353. doi: 10.1016/j.jvb.2012.09.001

Suutari, V., Brewster, C., Mäkel,ä, L., Dickmann, M., and Tornikoski, C. (2018). The effect of international work experience on the career success of expatriates: a comparison of assigned and self-initiated expatriates. Hum. Resour. Manage. 57, 37-54. doi: 10.1002/hrm.21827

Tims, M., Bakker, A. B., and Xanthopoulou, D. (2011). Do transformational leader enhance their followers' daily work engagement? Leadersh. Q. 22, 121-131. doi: 10.1016/j.leaqua.2010.12.011

Vigoda-Gadot, E., Eldor, L., and Schohat, L. M. (2013). Engage them to public service: conceptualization and empirical examination of employee engagement in public administration. Am. Rev. Public Admin. 43, 518-538. doi: $10.1177 / 0275074012450943$
Vincent-Höper, S., Muser, C., and Janneck, M. (2012). Transformational leadership, work engagement, and occupational success. Career Dev. Int. 17, 663-682. doi: 10.1108/13620431211283805

Wirtz, N., Rigotti, T., Otto, K., and Loeb, C. (2017). What about the leader? Crossover of emotional exhaustion and work engagement from followers to leaders. J. Occup. Health Psychol. 22, 86-97. doi: 10.1037/ocp 0000024

Xanthopoulou, D., Bakker, A. B., Demerouti, E., and Schaufeli, W. B. (2007). The role of personal resources in the job demands-resources model. Int. J. Stress Manag. 14, 121-141. doi: 10.1037/1072-5245.14.2.121

Zacher, H. (2014). Career adaptability predicts subjective career success above and beyond personality traits and core self-evaluations. J. Vocat. Behav. 84, 21-30. doi: $10.1016 /$ j.jvb.2013.10.002

Zettler, I., and Hilbig, B. E. (2010). Honesty-humility and a person-situation interaction at work. Eur. J. Pers. 24, 569-582. doi: 10.1002/per.757

Zhu, W., Avolio, B. J., and Walumbwa, F. O. (2009). Moderating role of follower characteristics with transformational leadership and follower work engagement. Group Organiz. Manage. 34, 590-619. doi: $10.1177 / 1059601108331242$

Conflict of Interest: The authors declare that the research was conducted in the absence of any commercial or financial relationships that could be construed as a potential conflict of interest.

Copyright (C) 2021 Chen, Yang, Deng, Lu and He. This is an open-access article distributed under the terms of the Creative Commons Attribution License (CC BY). The use, distribution or reproduction in other forums is permitted, provided the original author(s) and the copyright owner(s) are credited and that the original publication in this journal is cited, in accordance with accepted academic practice. No use, distribution or reproduction is permitted which does not comply with these terms. 